\title{
Apple powdery mildew caused by Podosphaera leucotricha: some aspects of biology
}

\author{
Holb, I.J. \\ University of Debrecen, Faculty of Agriculture, Institute of Horticulture, \\ 138. Böszörményi str., Debrecen, H-4032, Hungary (holb@agr.unideb.hu)
}

\begin{abstract}
Summary: Apple powdery mildew (Podoshphaera leucorticha) occurs wherever apples are grown. One of the most important fungal disease of apple which causing severe econimic loss on susceptible apple cultivars. Biology of the pathogen is widely investigated all over the world in the past 100 years. In this review, a summary from this enormous research is made for biology of apple powdery mildew in the following aspects: geographical distribution, morphology, taxonomy of the causal agent, symptoms, host susceptibility, resistance durability and disease cycle.
\end{abstract}

Key words: Malus $x$ domestica Bork., apple powdery mildew, Podoshphaera leucorticha, geographical distribution, symptoms, host susceptibility, disease cycle, biology

\section{Introduction}

Apple powdery mildew (Podoshphaera leucorticha) is a wordwide known fungal pathogen of apple. A key important fungal disease of apple which causing severe econimic loss on susceptible cultivars in every years where apple are grown (Hickey \& Yoder, 1990). Biology of the pathogen is widely investigated all over the world in the past 100 years. Thousands of publications were aimed to investigate the pathogen features and to understand biology of this disease in order to improve powdery mildew forecasting and disease management. The aim of this review was to prepare a summary for biology of apple powdery mildew including geographical distribution, morphology, taxonomy of the causal agent, symptoms, host susceptibility, resistance durability and disease cycle.

\section{Geographical distribution}

Powdery mildew occurs wherever apples are grown. It can be both major and minor importance of the disease in commercial orchards but it is an important disease in apple nurseries worldwide (Hickey \& Yoder, 1990). Economic loss dependent upon climatic conditions, cultivar susceptibility and orchard or nursery management practices. The management of powdery mildew in commercial orchards needs to be integrated with other apple diseases such as apple scab.

\section{Taxonomy, causal organism and its morphology}

Podosphaera genus within the Erysiphaceae family is commonly recognized as superficialmycelium, dichotomously branched appendages at tip and chasmothecium (formerly cleistothecium) with one ascus (Salmon, 1900). The Erysiphaceae are called obligate parasites. On conventional media, such as potato dextrose agar, powdery mildew conidia may form short germ tubes with septa (Yossifovitch, 1923), but these germ tubes soon die.

Podosphaera leucotricha (Ell. \& Ev.) E. S. Salmon (anamorph Oidium farinosum Cooke), an ascomycetous heterothallic fungus, causes powdery mildew of apple, pear and quince (Hickey \& Yoder, 1990). Conidia (20-38 $\mu \mathrm{m})$ are ellipsoidal and are produced on long chains on thin amphigenous mycelium. Chasmothecia are subglobose (75$96 \mu \mathrm{m}$ in diameter) and have apical and basal appendages. The apical appendages ( 3 to 11 per chasmothecia) are brown basally and widely spreading; their length is 3 to 7 times the diameter of the chasmothecia. The apex is undivided once or twice dichotomously branched. The basal appendages are rudimentary, pale brown, and simple or irregularly branched. Ones ascus $(55-70 \times 44-50 \mu \mathrm{m})$ can be found in the chasmothecia, which are oblong to subglobose. Eight ovate to elliptical ascospores $(22-36 \times 12-15 \mu \mathrm{m})$ are found in the ascus (Hickey \& Yoder, 1990).

\section{Symptoms}

The fungus attack twigs, foliage, blossoms and fruits. Infected twigs often are stunted and may die. When young leaves are infected, they tend to increase in length but not in width, and to become folded longitudinally (Ellis et al., 1981). Infections on leaves appear first on the lower surface. These lesions may spread to the upper surface and cover the entire leaf with a white spores and mycelium. Infections along the leaf margin often result in leaf curling or crinkling. 
Severely infected leaves sometimes abscise by midseason. In nureseries, the fungus can spread to all developing leaves and cause severe stunting of vegetative terminal shoot (Hickey \& Yoder, 1990).

Severely infected terminals have shortened internodes, and are covered with a silver-gray mycelium. The grayish white fungal growth turns brown, any many dark brown fruiting bodies appear (Hickey \& Yoder, 1990). Infected terminal and buds are more susceptible to winter injury than healthy buds. Infected flower buds are also exhibit reduced fruit set. In the spring, infected flower buds open a few days later than healthy onces. Blossoms and first leaves can be covered with mycelium and spores. The petals are often change their colour, distorted and stunted (Hickey \& Yoder, 1990).

Early fruit infection originated from diseased blossoms. Apple blossoms emerging from infected buds may give rise to small, russeted fruit. Infected fruits is covered with a network pattern of cork cells (Hickey \& Yoder, 1990).

\section{Host susceptibility and durability of resistance}

One of the firts detailed studies on powdery mildew suceptibilities of apple cultivars were prepared by Aldwinckle (1974) and Norton (1981), which included all important cultivars form the US.

Borovinova (1982a) studied the susceptibility of 59 apple cultivars to powdery mildew in a multi-year study. Most cultivars were infested by powdery mildew, but to a different extent. Only cultivar Kolotny was very slightly susceptible with the degree of $1 \%$ disease incidence. Cultivars Linda, Gray Renette, Boiken, White Winter Kalvil, Rik's Renette, Renette des Grandes Villes, Beforest, Jonathan, Fenuette Grise, Fenuette Rouge, Wellington, Jonathan and Pepin Shafran were highly susceptible to powdery mildew with a disease incidence above $20 \%$.

Borovinova (1982b) investigated the effect of the mineral fertilizers on the sensitivity of $\mathrm{cv}$. Jonathan to powdery mildew. She found that the application of $\mathrm{N}_{2} \mathrm{P}_{2} \mathrm{O}_{5}$ and $\mathrm{K}_{2} \mathrm{O}$ by $100,40,40 \mathrm{mg}$ active ingredient per $1 \mathrm{~kg}$ dry soil, increased the sensitivity of Jonathan to powdery mildew.

According to Jeger et al. (1986) the association between the resistance components permitted resistance to be classified as very high for cv. Discovery, very low for cv. Golden Delicious or intermediate for cvs. Bramley's Seedling, Suntan.

According to Cimanowski et al. (1988), Liberty, Macfree, Paulared, Priam and Priscilla can be ranked as susceptible to apple powdery mildew, while the cultivars James Grieve, Prima, Redfree, Tydeman's Red are less susceptible to the disease.

Apple cultivars considered moderately to highly susceptible include Jonathan, Baldwin, Cortland, Idared, Rome Beauty, Monroe, Gravenstein, Stayman Winesap,
Cox's Orange Pippin, Granny Smith, and Prima. Less susceptible cultivars include Delicious, Golden Delicious, Winesap, York Imperial, Nittany and Lord Lambourbe (Hickey \& Yoder, 1990).

Borovinova (1994) studied the susceptibility of scab resistant apple varieties to powdery mildew. All the evaluated varieties were susceptible to powdery mildew but to a different degree. Cultivar Moira was the most susceptible. According to her resarch, evaluated cultivars do not require any special control against powdery mildew.

Pedersen et al. (1994) studied the susceptibility of 15 apple cultivars to powdery mildew the results of which were compared with foundings of other researchers. All other works on powdery mildew suscpetibility of apple cultivars are partially summarized in Table 1 .

Table 1: Sampled literature sources for susceptibilty of some apple cultivars to Podoshpaera leucotricha

\begin{tabular}{|c|c|}
\hline Cultivar & Susceptibility to powdery mildew \\
\hline 'Belle de Boskoop' & $\begin{array}{l}\text { Low (Mygind, 1965; Pedersen et al., 1994; } \\
\text { Cimanowski et al., 1988) }\end{array}$ \\
\hline 'Bramleys Seedling & $\begin{array}{l}\text { Low (Mygind, 1963; Pedersen et al., 1994; Jeger } \\
\text { et al., 1986; Norton, 1981) }\end{array}$ \\
\hline 'Cox's Orange' & $\begin{array}{l}\text { Medium (Pedersen et al., 1994; Jeger et al., 1986; } \\
\text { Mygind, 1963), high (Jeger \& Butt, 1983, 1986; } \\
\text { van der Scheer, 1989; Hickey \& Yoder, 1990) }\end{array}$ \\
\hline 'Discovery' & $\begin{array}{l}\text { Low (Pedersen et al., 1994; Jeger \& Butt, 1983, } \\
\text { 1986; Jeger et al., 1986; Norton, 1981; van der } \\
\text { Scheer, 1989) }\end{array}$ \\
\hline 'Elstar' & Medium (van der Scheer, 1989) \\
\hline 'Filippa' & Low (Pedersen et al., 1994; Mygind, 1963) \\
\hline 'Gravenstein' & $\begin{array}{l}\text { Low (Aldwinckle, 1974; Norton, 1981), medium } \\
\text { (Pedersen et al., 1994), high (Mygind, 1963; } \\
\text { Hickey \& Yoder, 1990) }\end{array}$ \\
\hline 'Golden Delcicious' & Low (Jeger et al., 1986; Hickey \& Yoder, 1990) \\
\hline 'Guldborg' & $\begin{array}{l}\text { Medium (Pedersen et al., 1994), high (Mygind, } \\
\text { 1963) }\end{array}$ \\
\hline 'Idared' & High (Hickey \& Yoder, 1990) \\
\hline 'Ildrod Pigeon' & High (Pedersen et al., 1994; Norton, 1981) \\
\hline 'Ingrid Marie' & $\begin{array}{l}\text { Low (Pedersen et al., 1994; low-medium } \\
\text { (Mygind, 1963) }\end{array}$ \\
\hline 'James Grieve' & $\begin{array}{l}\text { Low (Pedersen et al., 1994; Cimanowski et } \\
\text { al.,1988) }\end{array}$ \\
\hline 'Jonathan' & $\begin{array}{l}\text { High (Aldwinckle, 1974; Norton, 1981; } \\
\text { Borovinova, 1982ab; Hickey \& Yoder, 1990) }\end{array}$ \\
\hline 'Jonagold' & Medium to high (van der Scheer, 1989) \\
\hline 'Mutsu' & $\begin{array}{l}\text { Low (Pedersen et al., 1994; Norton, 1981), } \\
\text { medium (Aldwinckle, 1974) }\end{array}$ \\
\hline 'Moria' & Medium (Borovinova, 1994) \\
\hline 'Prima' & $\begin{array}{l}\text { High (Hickey \& Yoder, 1990), low to medium } \\
\text { (van der Scheer, 1989; Cimanowski et al.,1988) }\end{array}$ \\
\hline 'Red Ananas' & Low (Pedersen et al., 1994) \\
\hline 'Skovfoged' & Medium (Pedersen et al., 1994) \\
\hline 'Summerred' & $\begin{array}{l}\text { Medium (Pedersen et al., 1994; Aldwinckle, 1974; } \\
\text { Norton, 1981; van der Scheer, 1989), }\end{array}$ \\
\hline $\begin{array}{l}\text { 'Transparente } \\
\text { Blanche' }\end{array}$ & $\begin{array}{l}\text { Medium (Pedersen et al., 1994; Aldwinckle, } \\
\text { 1974), high (Mygind, 1963) }\end{array}$ \\
\hline
\end{tabular}


Selection for resistance to powdery mildew, caused by $P$. leucotricha, is based mainly on major resistance genes, which provide a high level of resistance (Lespinasse, 1983; Fischer, 1994; Krüger, 1994). Monogenic or oligogenic resistances have been identified in wild Malus species such as Malus robusta (Pl1), Malus zumi (Pl2) and Mildew Immune Selection (MIS), or in ornamental crab apples such as White Angel (Plw) and the D series (Pld) (Knight \& Alston, 1968; Dayton, 1977; Visser \& Verhaegh, 1979; Korban \& Dayton, 1983; Gallott et al., 1985). The use of cultivars carrying major resistance genes often results in a selection of virulent isolates in pathogen populations, which are able to overcome the resistance (Parisi et al., 1993; Wolfe \& McDermott, 1994; Lebeda \& Zinkernagel, 2003). Resistance and its durability were widely investigated in France. The resistance from $M$. zumi were used mainly in the apple-breeding programme developed at the INRA in France. This resistance was initially considered to be the result of one dominant gene (Knight \& Alston, 1968), but additional studies have shown that it might be more complex (Seglias \& Gessler, 1997) and at least two genes may be involved (Alston, 1976). The source of resistance in $M$. zumi was considered to involve at least one single major resistance gene, named $P l 2$. The resistance introgressed from $M$. zumi was reported as stable under field conditions (Krïger, 1994), even over 17 years in unsprayed orchards (Alston, 1983). However, in later years in France, an increase of susceptibility to powdery mildew was observed on apple genotypes carrying Pl2 gene (Caffier \& Laurens, 2005). This increase of susceptibility could not be explained by tree age and/or by the amount of inoculum on expression of the resistance $P l 2$ gene. It was demonstrated that that isolates of $P$. leucotricha sampled in this orchard were virulent to $P l 2$ gene. Six years after planting of several apple genotypes with $P l 2$ gene resulted in a breakdown of the resistance. Ten years after planting, the percentage of genotypes that were still resistant to powdery mildew varied between 2 and $56 \%$ depending on the progenies. This suggested that additional quantitative resistance genes may influence the durability of resistance Pl2 (Caffier \& Laurens, 2005).

\section{Disease cycle}

P. leucotricha is an obligate parasite that overwinters as mycelium in dormant buds infected during the previous growing season (Woodward, 1927; Butt, 1971, 1972). Overwintering of the fungus is limited primarily by temperature. Infected buds are often failed to burst after a severe winters, The survival rate of these buds below $-20{ }^{\circ} \mathrm{C}$ is less than $5 \%$, while healthy buds can survive the temperatures of $-30{ }^{\circ} \mathrm{C}$ (Covey, 1969). Temperatures below $-12{ }^{\circ} \mathrm{C}$ can kill the mycelium int he infected buds and allow the buds to produce healthy leaves (Hickey \& Yoder, 1990).
At bud burst, conidia produced on overwintering mycelium in the infected bud, initiate the primary infections. These conidia infect young leaves, blossoms and fruit and provide inoculum for secondary disease cycles. Infections are regulated by temperatures and relative humidity. Young leaves are highly susceptible to the disease. At $10-25{ }^{\circ} \mathrm{C}$ (the optimum is $20-22{ }^{\circ} \mathrm{C}$ ) conidia can germinate between 4 and $30{ }^{\circ} \mathrm{C}$ (the optimum is $20-22{ }^{\circ} \mathrm{C}$ ), the required relative humidity ranged between 70 to $100 \%$. Germination is slow at temperatues below $4-10{ }^{\circ} \mathrm{C}$ and above $28-30{ }^{\circ} \mathrm{C}$ (Covey, 1968; Hickey \& Yoder, 1990).

Fruit buds provide the earliest source of inoculum. Because infected buds usually open a few days later than healthy ones, susceptible tissue is already present when the first conidia are produced (Hickey \& Yoder, 1990).

Production, dissemination and germination of conidia occur mainly during the light portion of the day (Yarwood, 1934; Burchill, 1965; Butt \& Jeger, 1986). Maturation of conidia in P. leucotricha is also diurnal (Childs, 1940). The fungus releases spores with a diurnal periodicity, and the highest concentration of spores in the air occurs from midday to early afternoon (Hickey \& Yoder, 1990; Xu et al., 1995).

Cunningham (1923) indicates that the abundant chasmotecia play no part in the overwintering of the fungus. It is widely accepted that the sexual stage of P. leucotricha do not appear to be important in the disease cycle. Although germination during the winter months have been reported but attempts to germinate ascospores and/or to inoculate foliage with them have been unsuccessful (Hickey \& Yoder, 1990)

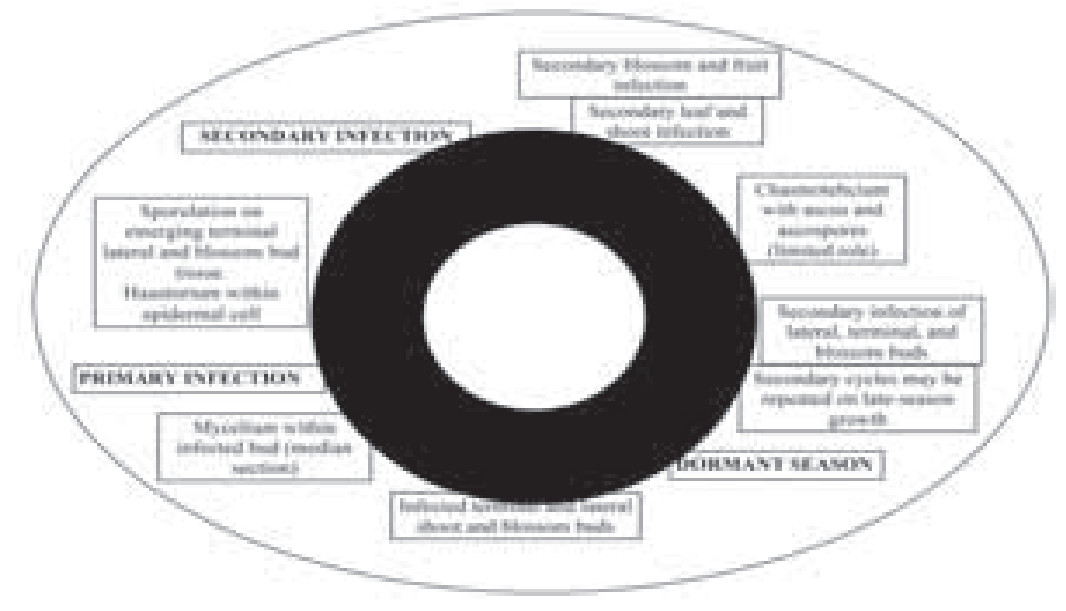

Figure 1: Disease cycle of Podosphaera leucortica

\section{Acknowledgements}

This research was supported partly by a grant of the Hungarian Scientific Research Fund (OTKA K108333), EU7 PURE programme and by the European Union and the State of Hungary, co-financed by the European Social Fund in the framework of TÁMOP-4.2.4.A/ 2-11/1-2012-0001 'National Excellence Program' under the project number: A2-SZJTOK-13-0061. 


\section{References}

Aldwinckle, H. S. (1974): Field susceptibility of 51 apple cultivars to apple scab and apple powdery mildew. Plant Disease Reporter 58: 625-629.

Alston, F. H. (1976): Practical aspects of breeding for mildew (Podosphaera leucotricha) resistance in apples. In: Proceedings of Eucarpia Meeting on Tree Fruit Breeding, Wageningen, The Netherlands, Institute for Horticultural Plant Breeding, 4-17.

Alston, F. H. (1983): Progress in transferring mildew (Podosphaera leucotricha) resistance from Malus species to cultivated apple. IOBS WPRS Bulletin 6: 87-95.

Borovinova, M. (1982a): Susceptibility of some apple cultivars to powdery mildew (Podosphaera leucotricha (Ell. et Ev. Salmon) in the region of Kyustendil. Horticultural and Viticultural Science 19(8): 50-55.

Borovinova, M. (1982b): The effect of the mineral fertilizers on the sensitivity of the apple cultivar Jonathan to the powdery mildew (Podosphaera leucotricha /Ell. et Ev./ Salmon). Reports of Second National Symposium of Plant Immunity, Plovdiv. 1982. 3: 199-206.

Borovinova, M. (1994): Susceptibility of 9 scab resistant apple varieties to powdery mildew /Podosphaera leucotricha (Ell. et Ev.) Salmon/. Fourth Symposium on Plant Immunity to Diseases and Pests. November 7-11, 1994, Dobrich. 132-135.

Burchill, R. T. (1965): Seasonal fluctuations in spore concentrations of Podosphaera leucotricha (Ell. and Ev.) Salm. in relation to the incidence of leaf infections. Ann. Appl. Biol. 55: 409-415.

Butt, D. J. (1971): The role of the apple spray programme in the protection of fruit buds from powdery mildew. Annals of Applied Biology 68: 149-157.

Butt, D. J. (1972): The timing of sprays for the protection of terminal buds on apple shoots from powdery mildew. Annals of Applied Biology 72: 239-248.

Butt, D. J. and Jeger, M. J. (1986): Components of spore production in apple powdery mildew (Podosphaera leucotricha). Plant Pathology 35: 491-497.

Caffier, V. and Laurens, F. (2005): Breakdown of $P l 2$, a major gene of resistance to apple powdery mildew, in a French experimental orchard. Plant Pathology 54: 116-124.

Childs, J. F. L. (1940): Diurnal cycle of spore maturation in certain powdery mildews. Phytopathology 30: 65-73.

Cimanowski, J., Dzieciol, W. and Kowalik, B. (1988): Evaluation of susceptibility of 22 apple varieties to apple scab /Venturia inaequalis (Cooke) Aderh/ and apple powdery mildew /Podosphaera leucotricha (Ell. et. Ev.) Salm/. Fruit Science Reports 15(2): 81-84.

Covey, P. R. (1969): Effect of extreme cold on the overwintering of Podosphaera leucotricha. Plant Disease Reporter 53: 710-711.

Coyier, D. L. (1968): Effect of temperature on germination of Podosphaera leucotricha conidia. Phytopathology 58: 1047.

Cunningham, G. H. (1923): Powdery mildew. Podosphaera leucotricha. New Zeal. Jour. Agr. 26: 344-351.

Dayton, D. F. (1977): Genetic immunity to apple mildew incited by Podosphaera leucotricha. HortScience 12: 225-226.

Ellis, M.A., Ferree, D. C. and Spring, D. E. (1981): Photosynthesis, transpiration, and carbohydrate content of apple leaves infected by Podosphaera leucotricha. Phytopathology 71: 392-395.

Fischer, C. (1994): Using wild Malus species and apple cultivars for breeding for resistance. Erwerbsobstbau 36: 208-212.
Gallott, J. C., Lamb, R. C. and Aldwinckle, H. S. (1985): Resistance to powdery mildew from some small-fruited Malus cultivars. HortScience 20: 1085-1087.

Hickey, K.D. and K.S. Yoder. (1990): Apple powdery mildew. Pages 9-10 in A.L. Jones and H.S. Aldwinckle, ed. Compendium of Apple and Pear Diseases. Am. Phytopathol. Soc., St. Paul, MN. 100 pp.

Jeger, M. J. and Butt, D. J. (1983): Using partial resistance in the integrated control of apple powdery mildew. Bulletin SROP, WPRS bulletin. VI/4: 111-122.

Jeger, M. J. and Butt, D. J. (1986): Epidemics of apple powdery mildwe (Podosphaera leucotricha) in a mixed orchard. Plant Pathology 35: 498-505.

Jeger, M. J., Butt, D. J. and Swait, A. A. J. (1986): Components of resistance of apple to powdery mildew (Podosphaera leucotricha). Plant Pathology 35: 477-490.

Knight, R. L. and Alston, F. H. (1968): Sources of field immunity to mildew (Podosphaera leucotricha) in apple. Canadian Journal of Genetics and Cytology 10: 294-298.

Korban, S. S. and Dayton, D. F. (1983): Evaluation of Malus germplasm for resistance to powdery mildew. HortScience 18: 219-220.

Krüger, J. (1994): Observations on different mildew mildew sources used in apple breeding at Ahrensburg. In: Schmidt, H., Kellerhals, M., eds. Progress in Temperate Fruit Breeding. Dordrecht, the Netherlands, Kluwer Academic, 7-12.

Lebeda, A. and Zinkernagel V. (2003): Evolution and distribution of virulence in the German population of Bremia lactucae. Plant Pathology 52: 41-51.

Lespinasse, Y. (1983): Amélioration du pommier pur la résistance á l'oidium (Podosphaera leucotricha): premiers résultats concernant la virulence du champignon. In: IOBC WPRS Bulletin VI: 96-110.

Mygind, H. (1963): Meldug med saerlig omtale of aeblemeldug. Tidsshr. Planteavl 67: 255-320.

Mygind, H. (1965): Undersogelse af nogle faktorer som pavir ker aeblemelduggens livslob. Meldug med saerlig omtale of aeblemeldug. Tidsshr. Planteavl 69: 216-239.

Norton, R. A. (1981): Field susceptibility of apple cultivars to scab, Venturia inaequalis and powdery mildew, Podosphaera leucotricha in a cool, humid climate. Fruit Variety Journal 3: 2-5.

Parisi, L., Lespinasse, L., Guillaumes, J. and Krüger, J. (1993): A new race of Venturia inaequalis virulent to apples with resistance due to the $\mathrm{V}_{\mathrm{f}}$ gene. Phytopathology 83: 533-537.

Pedersen, H. L., Christensen, J. V. and Hansen, P. (1994): Susceptibility of 15 apple cultivars to apple scab, powdery mildew, canker and mites. Fruit Varieties Journal 48(2): 97-100.

Salmon, E. S. (1900): A monograph on the Erysiphaceae. Torrey Bot. Club. Mem. 9. 292 p.

Seglias, N. P. and Gessler, C. (1997): Genetics of apple powdery mildew resistance from Malus zumi (Pl2). Bulletin SROP 20: 105-109.

van der Scheer, H. A. T. (1989): Susceptibility of apple cultivars and selections to scab and powdery mildew in The Netherlands. OILB Bulletin WPRS. XII/6: 205-211.

Visser, T. and Verhaegh, J. J. (1979): Resistance to powdery mildew (Podosphaera leucotricha) of apple seedlings growing under glasshouse and nursery conditions. Proceedings of Eucarpia Fruit Section Symposium. Tree Fruit Breeding, Angers, France, 1979, 111-120. 
Wolfe, M. S. and McDermott, J. M. (1994): Population genetics of plant-pathogen interactions: the example of Erysiphe graminisHordeum vulgare pathosystem. Annual Review of Phytopathology 32: 89-113.

Woodward, R. C. (1927): Studies on Podosphaera leucotricha (Ell. and Ev) Salm. I. The mode of perennation. Trans. Brit. Mycol. Soc. 12: 173-204.
Xu, X. M., Butt, D. J. and Ridout, M. S. (1995): Temporal patterns of airborne conidia of Podosphaera leucotricha, causal agent of apple powdery mildew. Plant Pathology 44: 944-955.

Yarwood, C. E. (1934): The diurnal cycle of development of Erysiphe polygoni. $86 \mathrm{p}$. $\mathrm{PhD}$ thesis, Univ. Wis.

Yossifovitch, M. (1923): Contributions á l'étude de l'Oidium de la vigne et son traitement. 176. p. Thesis, Univ. Toulouse. 